\title{
Identifikasi Kandungan Logam Timbal (Pb) Pada Buah Nangka (Artocarpus Heterophyllus) Di Media Jalan Kota Bandar Lampung
}

\author{
Identification of Thermal Metal Content (Pb) on Restricted Art (Artocarpus \\ heterophyllus) In The Media City Of Bandar Lampung
}

Rama Wicaksa*, Agus Setiawan, Slamet Budi Yuwono, dan Samsul Bakri

University of Lampung

*E-mail : ricaksaa@gmail.com

\begin{abstract}
Lead $(\mathrm{Pb})$ is a heavy metal that naturally exists in the earth's crust and diffuses in small amounts through natural and artificial processes. This study aims to determine the amount of lead contained in the fruit jackfruit (Artocarpus heterophyllus) in the median street Bandar Lampung City. To know the factors that affect the lead content of jackfruit (Artocarpus heterophyllus) is done regression analysis. Research shows that the lead content of the jackfruit (Artocarpus heterophyllus) in the median of Bandar Lampung City road has exceeded the consumption limit, besides the factors affecting the lead content of the jackfruit (Artocarpus heterophyllus) to be the tree season, the geometry of the bend, the topography of the incline and the derivative.
\end{abstract}

Keywords: Artocarpus heterophyllus, buah nangka, logam berat, timbal (Pb)

Disubmit : 17 Desember 2018 Diterima: 16 April 2018, disetujui: 28 Mei 2018

\section{PENDAHULUAN}

Kota Bandar Lampung merupakan salah satu Kota yang terus berkembang dari tahun ketahun, dalam perkembang yang terjadi diikuti pula dengan bertambahnya jumlah kendaraan bermotor di Kota Bandar Lampung, pertumbuhan dan jumlah kendaraan di Kota Bandar Lampung pada tahun 2014 yaitu sejumlah 2.755.953 kendaraan, sehingga akan mengakibatkan suatu kemacetan pada jalan-jalan tertentu (BPSBL, 2014). Peningkatan jumlah kendaraan akan diiringi oleh peningkatan jumlah polusi yang dihasilkan oleh kendaraan bermotor pada Kota Bandar Lampung, sebab kecepatan kendaraan yang melajur dengan jumlah kendaraan yang banyak akan mengakumulasi kandungan emisi yang dihasilkan oleh kendaraan bermotor salah satunya timbal (Pb) (Muziansyah, 2015).

Untuk mengurangi emisi yang dihasilkan kendaraan bermotor maka dilakukan penanaman pada hutan Kota dan jalur hijau. Kota Bandar Lampung melakukan penanaman pohon dan tumbuhan pada jalur hijau atau median jalan, jenis tanaman yang digunakan oleh pemerintah Kota Bandar Lampung salah satunya ialah jenis tanaman nangka (Artocarpus heterophyllus). Penanaman jenis tanaman nangka (Artocarpus heterophyllus) yang dilakukan pemerintah Kota Bandar Lampung sesuai dengan apa yang dikemukakan oleh (Dahlan, 2008) bahwa jenis tanaman nangka (Artocarpus heterophyllus) memiliki kemampuan daya serap emisi termasuk timbal.

Menurut (Widyasari et al., 2013) timbal merupakan logam berat yang terdapat secara alami pada bagian dalam kerak bumi dan tersebar kealam melalui proses alami. Timbal digunakan dalam campuran bensin untuk meningkatkan kinerja pembakaran, Indonesia meurupakan salah satu negara tertinggal sebab dibeberapa negara sudah tidak menggunakan timbal sebagai campuran bensin (Witoelar R., 2005). Timbal merupakan 
Rama Wicaksa: Identifikasi kandungan logam timbal (pb) pada buah nangka (Artocarpus heterophyllus) ..

satu logam yang bersifat toksik, jika terakumulasi mahluk hidup maka berpotensi memicu keracunan bahkan untuk jangka panjang akan menyebabkan kematian (Widyasari et al., 2013 \& Maksum, 2013).

Menjadi hal yang begitu menarik untuk dilakukan suatu penelitian mengenai kandungan timbal yang berada pada buah nangka, sebab terlepasnya kandungan timbal $(\mathrm{Pb})$ pada udara bebas yang dihasilkan oleh kendaraan bermotor dikhawatirkan akan mempengaruhi kandungan suatu tanaman yang ada disekitar jalan, sering kita jumpai masyarakat menyukai untuk mengonsumsi buah nangka baik dalam keadaan matang buah atau matang masakan hingga menjadi suatu produk olahan minuman dan lainnya, sehingga buah nangka (Artocarpus heterophyllus) yang terkandung timbal melebihi batas kandungan menjadi sangat berbahaya untuk dikonsumsi masyarakat (Rukman, 1998).

\section{METODE PENELITIAN}

Penelitian ini dilaksanakan di 7 (tujuh) median jalan Kota Bandar Lampung yang ditanami nangka yaitu, Jl. Kapten Abdul Haq, Jl. Zainal Abidin Pagar Alam, Jl. Teuku Umar, Jl. Sumantri Brojonegoro, Jl. Sultan Agung, Jl. Mayjen HM Ryacudu, Jl. Letjen Alamsyah Ratuparawinegara. Analisis sampel buah nangka dilakukan di laboratorium Kimia Universitas Lampung pada bulan Juli - Agustus 2017.

Objek dan Alat Penelitian. Objek penelitian adalah buah nangka pada median jalan Kota Bandar Lampung yang di ambil dari 7 jalan lokasi penelitian. Sebanyak 30 sampel buah nangka diambil dan dianalisis. Alat yang digunakan perlengkapan alat tulis, kamera, komputer, gunting ranting, pitameter, haga altimeter, meteran, seperangkat instrumen Spektro Serapan Atom (SSA), dan software Minitab 16.

Cara pengambilan sampel. Pengambilan sampel dilakukan dengan beberapa tahapan, pertama menentukan sampel pohon yang akan digunakan, selanjutnya lakukan pengukuran tinggi pohon menggunakan Christen meter, pengukuran diameter batang pohon dilakukan menggunakan pita meter, pengukuran kelebatan daun pohon menggunakan aplikasi habitapp sehingga langsung mendapatkan berapa persen dari kelebatan dau pohon tersebut, ketinggian buah pohon diukur dengan carapengukuran buah dari dari dasar permukaan tanah, usia pohon didapatkan berdasarkan keterangan masyarakat sekita, pengukuran kandungan udara lingkungan sekitar pohon diukur menggunakan RH Meter AMF062, keberadaan pohon lain dicatat sesuai lokasi, data kepadatan lalu lintas diambil dengan cara sensus kendaraan 1×24 jam tiap lokasi sampel, jarak pohon dari lampu merah didatkan dengan pengukuran menggunakan meteran, topografi jalan tikungan, perempatan, dan lurusan, geometri jalan tanjakan, turunan dan dataran dicatat sesuai kondisi letak sampel, lebar jalan dilakukan pengukuran menggunakan meteran dan jumlah lajur jalan dihitung sesuai jumlah lajur jalan yang terdapat pada lokasi. Selanjutnya dilakukan pengambilan sampel buah dan dilakukan pemotongan buah dengan ukuran 5x5 $\mathrm{cm}$ untuk selanjutnya dibawa ke laboratorium untuk dilakukan analisis menggunakan metode analisis Spektro Serapan Atom (SSA).

Analisis Sampel . Analisis sampel dilakukan di Laboratorium Kimia Universitas Lampung yang selanjutnya akan dilakukan Analisis Spektro Serapan Atom (SSA) untuk mendapatkan kandungan timbal $(\mathrm{Pb})$ pada buah nangka.

Analisis Data. Data yang terkumpul kemudian dianalisis menggunakan persamaan regresi linear. Model yang digunakan pada penelitian ini yaitu (Law \& Kelton, 1991).

\section{HASIL DAN PEMBAHASAN}

Kondisi Jl. Kapten Abdul Haq. Kondisi tegakan pada median jalan ini tergolong padat dan rapat sebab jarak tanaman satu dan lainnya hanya 2,5 m. Bentuk tajuk yang ditemukan ialah berbentuk membulat dan payung dengan ketinggian tanaman berkisa 2-8 m, jenis tanaman yang dapat ditemukan pada median jalan selain tanaman nangka ialah jenis tanaman kerai payung (Filicium decipiens), dan mahoni (Swietenia Mahagoni). Pada Jl. Kapten Abdul Haq geometri jalannya berbentuk perematan pada sampel 1, tikungan pada 
sampel 2, dan lurusan pada sampel 3 dan 4. Untuk topografi jalan berbentuk dataran pada sampel 1-3 dan berbentuk tanjakan pada sampel 4 .

Kondisi Jl. Zainal Abidin Pagar Alam. Kondisi tegakan pada median jalan ini memiliki jarak tanam antara 2-3 m, dengan bentuk tajuk yang berbentuk membulat dan payung dengan ketingian tanaman berkisar 1,5-6 m. Jenis tanaman yang dapat ditemukan pada median jalan selain tanaman nangka ialah jenis tanaman mahoni (Swietenia Mahagoni), palem (Dryophloeus Beguinii), Kurma (Phoenix dactylifera) dan tanaman hias pucuk merah (Syzygium oleana). Pada Jl. Zainal Abidin Pagar Alam geometri jalannya berbentuk tikungan pada sample 2 dan lurusan pada sampel 1, 3 dan 5. Untuk topografi jalan berbentuk tanjakan pada sample 3 dan dataran pada sampel 1, 2 dan 4.

Kondisi JL. Teuku Umar . Kondisi tegakan pada median jalan ini memiliki jarak tanam antara 2-3 m, dengan bentuk tajuk yang berbentuk membulat dan payung dengan ketingian tanaman berkisar 0,50-8 m. Jenis tanaman yang dapat ditemukan pada median jalan selain tanaman nangka ialah jenis tanaman mahoni (Swietenia mahagoni), palem (Dryophloeus beguinii), keray payung (Filicium decipiens), bungur (Lagerstromiia speciosa), tanaman hias pucuk merah (Syzygium oleana), bunga kertas (Bougainvillea). Pada JL. Teuku Umar geometri jalannya berbentuk tikungan pada sample 3 dan lurusan pada sampel 1, 2, 4 dan 5. Untuk topografi jalan berbentuk turunan pada sampel 1 dan 5 tanjakan pada sample 3 dan 4 dataran pada sampel 2.

Kondisi JL. Sumantri Brojonegoro. Kondisi tegakan pada median jalan ini memiliki jarak tanam antara 1-4 m, dengan bentuk tajuk yang berbentuk membulat dan payung dengan ketingian tanaman berkisar 1-8 m. Jenis tanaman yang dapat ditemukan pada median jalan selain tanaman nangka ialah jenis tanaman mahoni (Swietenia Mahagoni), Sawo kecik (Manilkara kauki), Sawo kecik (Manilkara kauki) palem (Dryophloeus Beguinii), kamboja (Plumeria), bunga kertas (Bougainvillea). Pada JL. Sumantri Brojonegoro geometri jalannya berbentuk perempatan pada sample 3 dan lurusan pada sampel 1, 2 dan 4. topografi jalan berbentuk dataran pada keempat samplenya.

Kondisi JL. Myjen HM Ryacudu . Kondisi tegakan pada median jalan ini memiliki jarak tanam antara 2-3 m, dengan bentuk tajuk yang berbentuk membulat dan payung dengan ketingian tanaman berkisar 1-8 $\mathrm{m}$. Jenis tanaman yang dapat ditemukan pada median jalan selain tanaman nangka ialah jenis tanaman mahoni (Swietenia Mahagoni), keray payung (Filicium decipiens), bungur (Lagerstromiia speciosa), Sawo kecik (Manilkara kauki), tanaman hias pucuk merah (Syzygium oleana), bunga kertas (Bougainvillea). Pada JL. Myjen HM Ryacudu geometri jalannya berbentuk tikungan pada sample 2, perempatan sampel 3 dan lurusan pada sampel 1 dan 4 . Untuk topografi jalan berbentuk dataran pada keempat samplenya.

Kondisi JL. Letjen Alamsya Ratuparawinegara. Kondisi tegakan pada median jalan ini memiliki jarak tanam antara 2-3 m, dengan bentuk tajuk yang berbentuk membulat dan payung dengan ketingian tanaman berkisar 2-8 m. Jenis tanaman yang dapat ditemukan pada median jalan selain tanaman nangka ialah jenis tanaman mahoni (Swietenia Mahagoni), keray payung (Filicium decipiens), bungur (Lagerstromiia speciosa), sonokeling (Dalbergia latifolia). Pada JL. Letjen Alamsya Ratuparawinegara geometri jalannya berbentuk perempatan pada sampel 2 dan lurusan pada sampel 1,3 dan 4. Untuk topografi jalan berbentuk tanjakan terdapat pada sampel 4. Sampel 1, 2 dan 3 berbentuk dataran.

Kondisi JL. Sultan Agung. Kondisi tegakan pada median jalan ini memiliki jarak tanam antara 2-3 m, dengan bentuk tajuk yang berbentuk membulat dan payung dengan ketingian tanaman berkisar 2-8 $\mathrm{m}$. Jenis tanaman yang dapat ditemukan pada median jalan selain tanaman nangka ialah jenis tanaman mahoni (Swietenia Mahagoni), keray payung (Filicium decipiens), bungur (Lagerstromiia speciosa), sonokeling (Dalbergia latifolia), ketapang (Terminalia catappa), tanaman hias pucuk merah (Syzygium oleana), dan bunga kertas (Bougainvillea). Pada JL. Letjen Alamsya Ratuparawinegara geometri jalannya berbentuk perempatan pada sampel 2 dan lurusan pada sampel 1, 3 dan 4. Untuk topografi jalan berbentuk tanjakan terdapat pada sampel 4. Sampel 1, 2 dan 3 berbentuk dataran. 
Rama Wicaksa: Identifikasi kandungan logam timbal (pb) pada buah nangka (Artocarpus heterophyllus) ..

Nilai Kandungan Rataan Timbal Buah Nangka (Artocarpus heterophyllus). Kandungan timbal buah nangka pada median jalan Kota Bandar Lampung memiliki variasi yang beragam antara 0,46 - 1,94 ppm $(\mathrm{mg} / \mathrm{kg})$ namun berdasarkan rataan yang didapat kandungan timbal pada buah nangka di median jalan Kota Bandar Lampung tergolong tinggi dan melampaui batasan konsumsi buah, dengan rata-rata kandungan timbal pada buah nangka yaitu $1,05 \mathrm{ppm}(\mathrm{mg} / \mathrm{kg})$. Rataan kandungan timbal yang tergolong tinggi pada buah nangka disarankan kepada masyarkat Kota Bandar Lampung untuk tidak mengonsumsi buah nangka yang berasal dari median jalan sebab dengan konsumsi jangka panjang akan mengakumulasi kandungan timbal pada tubuh manusia dan mengakibatkan hal yang tidak diinginkan. Nilai kandungan rata-rata timbal buah nangka pada median jalan Kota Bandar Lampung secara lengkap disajikan pada Tabel 1.

Tabel 1. Kandungan rataan timbal buah nangka di median jalan Kota Bandar Lampung

\begin{tabular}{|c|c|c|c|c|}
\hline No & $\begin{array}{c}\text { No } \\
\text { Sampel }\end{array}$ & Nama jalan & $\begin{array}{c}\text { Kandungan Timbal (Pb) } \\
\text { ppm (mg/kg) }\end{array}$ & $\begin{array}{c}\text { Rataan Kandungan Timbal (Pb) } \\
\text { ppm (mg/kg) }\end{array}$ \\
\hline 1 & 2 & Jl. Kapten Abdul Haq & 0,46 & - \\
\hline 2 & 1 & Jl. Kapten Abdul Haq & 0,61 & - \\
\hline 3 & 3 & Jl. Kapten Abdul Haq & 0,98 & - \\
\hline 4 & 4 & Jl. Kapten Abdul Haq & 1,92 & 0,99 \\
\hline 5 & 6 & Jl. Zainal abidin Pagar A. & 0,48 & - \\
\hline 6 & 8 & Jl. Zainal abidin Pagar A. & 0,66 & - \\
\hline 7 & 5 & Jl. Zainal abidin Pagar A. & 0,97 & - \\
\hline 8 & 7 & Jl. Zainal abidin Pagar A. & 1,82 & 0,98 \\
\hline 9 & 10 & Jl. Teuku Umar & 0,94 & - \\
\hline 10 & 13 & Jl. Teuku Umar & 1,71 & \\
\hline 11 & 9 & J1. Teuku Umar & 1,73 & - \\
\hline 12 & 11 & Jl. Teuku Umar & 1,79 & - \\
\hline 13 & 12 & Jl. Teuku Umar & 1,94 & 1,62 \\
\hline 14 & 14 & Jl. S. Bojonegoro & 0,57 & - \\
\hline 15 & 17 & Jl. S. Bojonegoro & 0,63 & - \\
\hline 16 & 15 & Jl. S. Bojonegoro & 0,65 & - \\
\hline 17 & 16 & Jl. S. Bojonegoro & 0,67 & 0,62 \\
\hline 18 & 19 & Jl. Myjen HM Ryacudu & 0,60 & - \\
\hline 19 & 21 & Jl. Myjen HM Ryacudu & 0,72 & - \\
\hline 20 & 18 & Jl. Myjen HM Ryacudu & 0,77 & - \\
\hline 21 & 20 & J1. Myjen HM Ryacudu & 0,78 & 0,71 \\
\hline 22 & 22 & Jl. Letjen Alamsya R. & 0,78 & - \\
\hline 23 & 24 & Jl. Letjen Alamsya R. & 0,82 & - \\
\hline 24 & 23 & Jl. Letjen Alamsya R. & 0,95 & - \\
\hline 25 & 25 & Jl. Letjen Alamsya R. & 1,76 & 1,07 \\
\hline 26 & 29 & Jl. Sultan Agung & 0,66 & - \\
\hline 27 & 28 & Jl. Sultan Agung & 0,91 & - \\
\hline 28 & 30 & J1. Sultan Agung & 1,14 & - \\
\hline 29 & 27 & J1. Sultan Agung & 1,41 & - \\
\hline \multirow[t]{2}{*}{30} & 26 & J1. Sultan Agung & 1,80 & 1,18 \\
\hline & & Rataan & 1,05 & \\
\hline
\end{tabular}

Sumber: Data primer (2017)

Berdasarkan Tabel 2. Nilai kandungan rataan timbal buah nangka pada median jalan Kota Bandar Lampung cukup bervariasi, kandungan yang terendah adalah sebesar 0,63 ppm (mg/kg) di Jl. S. Brojonegoro dan kandungan tertinggi sebesar 1,62 ppm (mg/kg) di Jl. Teuku Umar. Rataan kandungan timbal pada buah nangka pada median jalan Kota Bandar Lampung sebesar $1,05 \mathrm{ppm}(\mathrm{mg} / \mathrm{kg})$. Hal ini menunjukan bahwa kandungan buah nangka melampaui batasan dari kandungan timbal (Badan Standardisasi Nasional Indonesia No. 7387,2009$)$ yaitu sebesar $0,50 \mathrm{ppm}(\mathrm{mg} / \mathrm{kg})$. Namun berdasarkan penelitian yang dilakukan oleh (Kartikasari, 2016) kandungan timbal yang terdapat pada buah apeljauh lebih tinggi yaitu sebesar 9,30 ppm $(\mathrm{mg} / \mathrm{kg})$. 


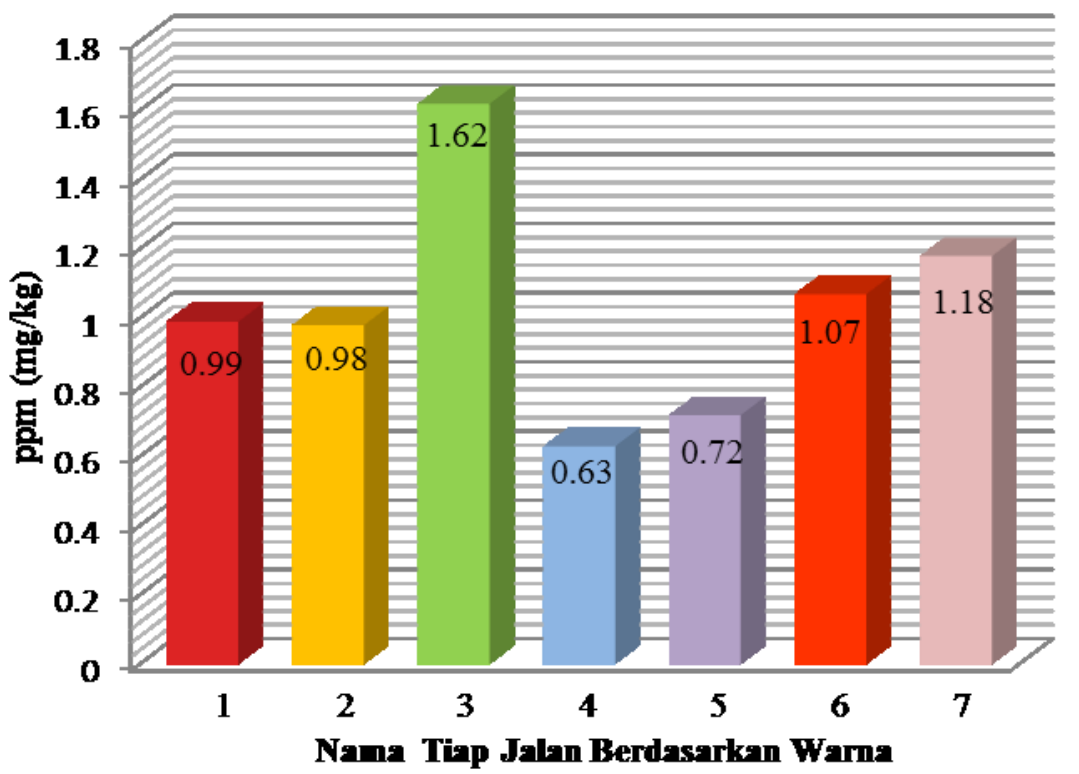

1 Jl. Kapten Abdul Haq

2 Jl. Zainal Abidin P.A

3 Jl. Tengku Umar

4 Jl. S. Brojonegoro

5 Jl. Myjen HM Ryacudu

6 Jl. Letjen Alamsyah

7 Jl. Sultan Agung

Gambar 1. Rata-rata kandungan timbal pada buah nangka pada media jalan Kota Bandar Lampung

Rata-rata kandungan timbal pada media jalan Kota Bandar Lampung melewati batasan yang digunakan pada (Badan Standardisasi Nasional Indonesia No. 7387, 2009) sebesar 0,50 ppm (mg/kg) sehingga disimpulkan bahwa kandungan timbal pada buah nangka pada median jalan Kota Bandar Lampung telah melewati batasan yang digunakan pada SNI No.7387 sebesar $0,05 \mathrm{ppm}(\mathrm{mg} / \mathrm{kg})$ sehingga bahwa buah nangka dari lokasi tersebut tidak layak dikonsusi oleh masyarakat Kota Bandar Lampung.

Kelayakan Konsumsi Buah Nangka (Artocarpus heterophyllus). Standar kelayakan konsumsi buah nangka ditetapkan menggunakan (Badan Standardisasi Nasional Indonesia No. 7387, 2009) mengenai batasan maksimum cemaran logam berat dalam pangan. Batasan standar $\mathrm{Pb}$ ialah $0,50 \mathrm{ppm}(\mathrm{mg} / \mathrm{kg})$ sehingga dari 30 sampel yang digunakan hanya terdapat 2 sampel yang dibawah standar sehingga masih layak untuk dikonsumsi, 2 sampel ini merupakan sampel pada jalan Jl. Kapten Abdul Haq dan Jl. Zainal Abidin Pagar Alam, pada Jl. Kapten Abdul Haq yang merupakan sampel ke-2 dengan kandungan timbal pada buah yaitu $0,48 \mathrm{ppm}(\mathrm{mg} / \mathrm{kg})$ tinggi pohon $5,5 \mathrm{~m}$, diameter batang pohon $20,06 \mathrm{~cm}$, dengan kelebatan daun yang lebat, ketinggian buah pohon $0,20 \mathrm{~m}$, usia pohon relatif sama yaitu 6 tahun, kandungan udara sekitar pohon $462 \mathrm{ppm}$, terdapat keberadaan pohon lain disekitarnya, jumlah kepadatan lalu lintas sebanyak 48,551 /hari, jarak pohon dari lampu merah yaitu $0,22 \mathrm{~km}$ atau sama dengan $220 \mathrm{~m}$, bentuk topografi tikungan, bentuk geometri dataran, lebar jalan 3,50 m dan jumlah lajur jalan yaitu 2 lajur. Di jalan Jl. Zainal Abidin Pagar Alam yang merupakan sampel ke-6 dengan kandungan timbal pada buah yaitu $0,48 \mathrm{ppm}(\mathrm{mg} / \mathrm{kg})$, tinggi pohon $2,50 \mathrm{~m}$, diameter batang pohon $9,55 \mathrm{~cm}$, dengan kelebatan daun yang tidak lebat, ketinggian buah pohon $0,90 \mathrm{~cm}$, usia pohon relatif sama yaitu 6 tahun, kandungan udara sekitar pohon 479 ppm, terdapat keberadaan pohon lain disekitarnya, kepadatan lalu lintas sebanyak 70,985 kendaraan/hari, jarak pohon dari lampu merah yaitu 0,86 $\mathrm{km}$ atau sama dengan $860 \mathrm{~m}$, bentuk topografi tikungan, bentuk geometri dataran, lebar jalan $9 \mathrm{~m}$ dan jumlah lajur jalan lainnya dari 2 lajur tepatnya 3 lajur jalan.

Nilai Rata-Rata Kandungan Timbal Buah Nangka (Artocarpus heterophyllus) Berdasarkan Topografi Jalan Dan Geometri Jalan. Berdasarkan data yang didapatkan dalam pengelompokan kandungan timbal sesuai topografi dan geometri jalan maka didapatkan hasil sebagai berikut : 
Rama Wicaksa: Identifikasi kandungan logam timbal (pb) pada buah nangka (Artocarpus heterophyllus) ..

Tabel 3. Nilai kandungan Rata-rata timbal buah nangka pada tiap bentuk topografi dan geometri jalan Kota Bandar Lampung

\begin{tabular}{llr}
\hline No & Bentuk Topografi dan Geometri Jalan & $\begin{array}{l}\text { Rata-rata Kandungan Timbal Pada buah nangka } \\
\text { (ppm } \mathbf{~ m g / k g )}\end{array}$ \\
\hline 1. & Tikungan & 0,7979 \\
2. & Perempatan & 0,7845 \\
3. & Lurusan & 1,1878 \\
4. & Tanjakan & 1,7393 \\
5. & Turunan & 1,6202 \\
6. & Dataran & 0,7315 \\
\hline
\end{tabular}

Sumber: Data primer (2017).

Dengan rata-rata kandungan timbal pada tiap bentuk geometri dan topografi jalan memiliki kandungan yang berbeda dan beragam menunjukan bahwa setiap bentuk jalan memili keterkaitan dengan pengaruh yang ditimbulkan atas kandungan timbal pada tiap buah yang berada pada median jalan, sebab tiap bentuk jalan baik topografi atau geometri akan mempengaruhi kecepatan angin, kecepatan kendaraan hingga kepadatan lalu lintas pada lokasi tersebut. Seperti pada kondisi topografi yang membentuk tikungan maka akan terjadi suatu pemecahan kandungan timbal diudara yang diakibatkan terhempas oleh kecepatan angin yang dibawa oleh kendaraan pada saat kondisi jalan lurus (Nauli, 2002 \& Muziansyah, 2015)

Kandungan dari buah nangka dipengaruhi oleh bentuk geometri dan topografi jalan sehingga hal ini akan mempengaruhi dari kondisi kecepatan angin dan kecepatan kendaraan (Badan Standarisasi Nasional No.T-14, 2004 \& Muziansyah, 2015) selain itu menurut (Kusminingrum et al., 2008) kondisi jalan yang lengan dan lurus akan mempengaruhi kodisi kandungan dan penumpukan emisi dalam suatu lokasi sebab kendaraan akan melaju cepat. Namun pada kondisi geometri jalan yang berbentuk tanjakan kendaraan akan mengalami kinerja yang lebih berat dan pengemudi akan menginjak pedal gas lebih dalam sehingga kendaraan akan menghasilkan emisi yang lebih besar, hal ini terjadi apabila jalan tersebut tidak dalam kondisi ramai dan macet, apabila jalan dalam kendaraan ramai dan macet kendaraan akan jauh lebih berat melakukan aktifitas kerja mesin kendaraan dan dengan rentan waktu keberadaan kendaraan yang jauh lebih lama (Kusminingrum et al., 2008 \& (Muziansyah, 2015).

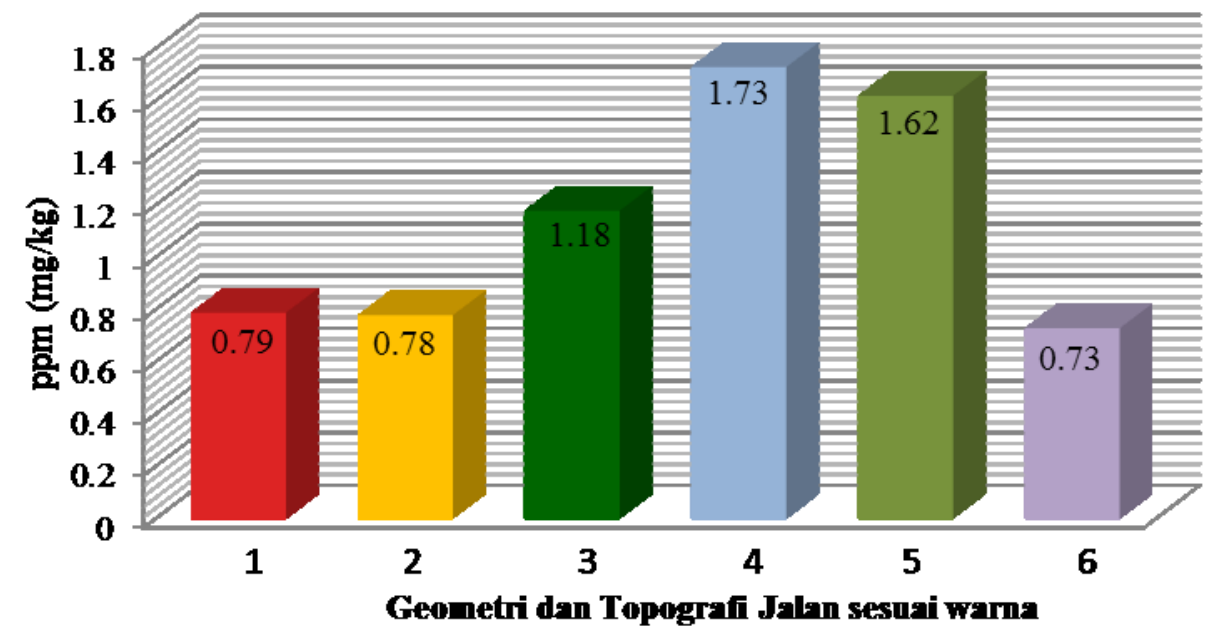

1 - Tikungan $2 \backsim$ Perempatan 3 eLurusan 4 - Tanjakan 5 - Turunan $6 \bowtie$ Dataran

Gambar 2. Rata-rata Kandungan timbal pada tiap bentuk jalan

Kandungan timbal $(\mathrm{Pb})$ pada tiap bentuk jalan baik topografi dan geometri memiliki rata-rata diatas 0,50 ppm (mg/kg) namun tiap kandungan pada bentuk jalan memiliki Variasinya masing-masing karna terdapat beberapa variabel yang mempengaruhi landungan timbal pada tiap bentuk median jalan. 
Variabel Berpengaruh. Terdapat Beberapa variabel yang berpengaruh terhadap kandungan timbal buah nangka antanya ialah; Usia Pohon, berdasarkan penelitian (Arman et al., 2010) semakin tua usia dari tanaman maka akan mempengaruhi kandungan timbal yang terdapat pada tanaman tersebut hal ini disebabkan oleh terakumulasinya kandungan timbal seusia dari tanamn tersebut. Geometri jalan bentuk tikungan dipengaruhi oleh kecepatan kendaraan sebab saat kendaraan melaju pada jalur lurus memecah kumpulan $\mathrm{Co}_{2}$ dan emisi kendaraan sehingga akan memecah kumpulan dari $\mathrm{Co}_{2}$ dan emisi kendaraan (Badan Standarisasi Nasional No.T-14, 2004).

Topografi Jalan bentuk tanjakan dan turunan, akan terjadi kemacetan dan terjadi penumpukan kendaraan dan mengakumulasi jumlah emisi yang dihasilkan dan pada kondisi jalan menanjak pengendara akan sering menekan pedal gas lebih dalam, kedua hal ini yang mengakibatkan kandungan timbal akan dihasilkan lebih banyak dan mempengaruhi kandungan pada buah nangka hal ini disebabkan karna kecepatan kendaraan akan meningkat, menurun, atau tetap. kecepatan kendaraan yang tinggi akan menghasilkan emisi kendaraan yang lebih besar namun dengan waktu yang cepat namun dengan kendaraan dengan kecepatan yang lambat akan menghasilkan emisi yang besar (Muziansyah, 2015 \& PT. Delima Laksana Tata, 2012).

\section{KESIMPULAN}

Berdasarkan hasil yang diperoleh, maka dapat disimpulkan bahwa buah nangka yang diperoleh dari median jalan tidak layak untuk dikonsumsi oleh masyarakat Kota Bandar Lampung karena memiliki rataan kandungan timbal sebesar 1,05 ppm (mg/kg). Kandungan timbal buah nangka pada median jalan Kota Bandar Lampung dipengaruhi oleh faktor, usia pohon, topografi jalan bentuk tikungan, geometri jalan bentuk tanjakan, dan geometri jalan bentuk turunan.

\section{DAFTAR PUSTAKA}

Arman, B. Dan Fatimah, N. 2010. Pengaruh Umur Eceng Gondok (Eichernia Crassipes) Dan Genjer (Limnocharius Flava) Terhadap Penyerapan Logam Pb, Cd Dan Cu Dalam Ember Perlakuan Dengan Metode Spektrofotometri Serapan Atom. Jurnal Fermasains, 1(2): 60-70.

Badan Standardisasi Nasional Indonesia No. 7387 2009. Batas maksimum cemaran mikroba dalam pangan. Bandan Standardisasi Indonesia. Jakarta, Indonesia.

Badan Standarisasi Nasional No.T-14 2004. Geometri Jalan Perkotaan. Jakarta, Indonesia.

BPSBL 2014. Jumlah kendaraan Bermotor di Kota Bandar Lampung.

Dahlan, E.N. 2008. JUMLAH EMISI GAS CO 2 DAN PEMILIHAN JENIS TANAMAN BERDAYA ROSOT SANGAT TINGGI : STUDI KASUS DI KOTA BOGOR ( The Amount of CO 2 Gasses Emission and Selection of Plant Species with Height Carbon Sink Capability : Case Study in Bogor Municipality ). Jurnal Media Konservasi, 13(2): 85-89.

Kartikasari, M. 2016. Analisis Kandungan Timbal (Pb) Pada Buah Apel (Pylus Malus L.) Dengan Metode Dekstruksi Basah Secara Spektrofotometri Serapan Atom. UIN Maulana Malik Ibrahim.

Kusminingrum, N. \& Gunawan G. 2008. Polusi Udara Akibat Aktivitas Kendaraan Bermotor Di Jalan PerKotaan Pulau Jawa Dan Bali. Jurnal RSDD, 5(1): 47-59.

Law, A.M, \& Kelton, W.D. 1991. Simulation Modeling Analisis. Singapore: Universitas of Arizona.

Maksum, T.S. 2013. KANDUNGAN CADMIUM DAN TIMBAL BUAH MANGROVE Bruguiera gymnorrhiza, Avicennia alba DAN Sonneratia caseolaris DARI MUARA SUNGAI MATI. Jurnal CAKRA KIMIA, 3(3): 84-88. 
Rama Wicaksa: Identifikasi kandungan logam timbal (pb) pada buah nangka (Artocarpus heterophyllus) ..

Muziansyah, D, dkk. 2015. Model Emisi Gas Buangan Kendaraan Bermotor Akibat Aktivitas Transportasi ( Studi Kasus: Terminal Pasar Bawah Ramayana Koita Bandar Lampung ) Terminal Pasar Bawah Ramayana kota bandar lampung. Model Emisi Gas Buangan Kendaraan Bermotor Akibat Aktivitas Transportasi (Studi Kasus: Terminal Pasar Bawah Ramayana Kota Bandar Lampung), 3(1): 57-70.

Nauli, T. 2002. POLA SEBARAN POLUTAN DARI CEROBONG ASAPPOLA SEBARAN POLUTAN DARI CEROBONG ASAP. Prosldlng Pertemuan dan Presentasilimiah Penelltlan Dasar IImu Pengetahuan dan Teknologl Nukllr P3TM-BATAN. hal.313-320.

PT. Delima Laksana Tata 2012. Studi Perhitungan Emisi CO2 Pada Setiap Kendaraan Bermotor. Program. Jakarta, Indonesia.

Rukman, R. 1998. Tanaman nangka. Yogyakarta, Indonesia.

Widyasari, N., Moelyaningrum, A.D. \& Pujiati, R.S. 2013. ANALISIS POTENSI PENCEMARAN TIMBAL ( $\mathrm{Pb}$ ) PADA TANAH , AIR LINDI DAN AIR TANAH ( SUMUR MONITORING ) DI TPA PAKUSARI KABUPATEN JEMBER Analysis of Potential Lead Pollution on Soil , Leachate and Ground Water ( MonitoringWells ) in Pakusari Landfill Jember. Artikel Ilmiah Hasil Penelitian Mahasiswa 2013. hal.1-8.

Witoelar R. 2005. Prosiding Pengujian Kualitas Bahan Bakar di 10 Kota Besar di Indonesia Proceeding of Fuel Quality Monitoring in 10 Big Cities in Indonesia Pendahuluan Prosiding Pengujian Kualitas Bahan Bakar di 10 Kota Besar di Indonesia Proceeding of Fuel Quality Monito. Prosiding Pengujian Kualitas Bahan Bakar di 10 Kota Besar di Indonesia. hal.1-60.

Arman, B. Dan Fatimah, N. 2010. Pengaruh Umur Eceng Gondok (Eichernia Crassipes) Dan Genjer (Limnocharius Flava) Terhadap Penyerapan Logam Pb, Cd Dan Cu Dalam Ember Perlakuan Dengan Metode Spektrofotometri Serapan Atom. Jurnal Fermasains, 1(2): 60-70.

Badan Standardisasi Nasional Indonesia No. 7387 2009. Batas maksimum cemaran mikroba dalam pangan. Bandan Standardisasi Indonesia. Jakarta, Indonesia.

Badan Standarisasi Nasional No.T-14 2004. Geometri Jalan Perkotaan. Jakarta, Indonesia.

BPSBL 2014. Jumlah kendaraan Bermotor di Kota Bandar Lampung.

Dahlan, E.N. 2008. JUMLAH EMISI GAS CO 2 DAN PEMILIHAN JENIS TANAMAN BERDAYA ROSOT SANGAT TINGGI : STUDI KASUS DI KOTA BOGOR ( The Amount of CO 2 Gasses Emission and Selection of Plant Species with Height Carbon Sink Capability: Case Study in Bogor Municipality ). Jurnal Media Konservasi, 13(2): 85-89.

Kartikasari, M. 2016. Analisis Kandungan Timbal (Pb) Pada Buah Apel (Pylus Malus L.) Dengan Metode Dekstruksi Basah Secara Spektrofotometri Serapan Atom. UIN Maulana Malik Ibrahim.

Kusminingrum, N. \& Gunawan G. 2008. Polusi Udara Akibat Aktivitas Kendaraan Bermotor Di Jalan PerKotaan Pulau Jawa Dan Bali. Jurnal RSDD, 5(1): 47-59.

Law, A.M, \& Kelton, W.D. 1991. Simulation Modeling Analisis. Singapore: Universitas of Arizona.

Maksum, T.S. 2013. KANDUNGAN CADMIUM DAN TIMBAL BUAH MANGROVE Bruguiera gymnorrhiza, Avicennia alba DAN Sonneratia caseolaris DARI MUARA SUNGAI MATI. Jurnal CAKRA KIMIA, 3(3): 84-88.

Muziansyah, D, dkk. 2015. Model Emisi Gas Buangan Kendaraan Bermotor Akibat Aktivitas Transportasi ( Studi Kasus: Terminal Pasar Bawah Ramayana Koita Bandar Lampung ) Terminal Pasar Bawah 
Ramayana kota bandar lampung. Model Emisi Gas Buangan Kendaraan Bermotor Akibat Aktivitas Transportasi (Studi Kasus: Terminal Pasar Bawah Ramayana Kota Bandar Lampung), 3(1): 57-70.

Nauli, T. 2002. POLA SEBARAN POLUTAN DARI CEROBONG ASAPPOLA SEBARAN POLUTAN DARI CEROBONG ASAP. Prosldlng Pertemuan dan Presentasilimiah Penelltlan Dasar IImu Pengetahuan dan Teknologl Nukllr P3TM-BATAN. hal.313-320.

PT. Delima Laksana Tata 2012. Studi Perhitungan Emisi CO2 Pada Setiap Kendaraan Bermotor. Program. Jakarta, Indonesia.

Rukman, R. 1998. Tanaman nangka. Yogyakarta, Indonesia.

Widyasari, N., Moelyaningrum, A.D. \& Pujiati, R.S. 2013. ANALISIS POTENSI PENCEMARAN TIMBAL ( $\mathrm{Pb}$ ) PADA TANAH , AIR LINDI DAN AIR TANAH ( SUMUR MONITORING ) DI TPA PAKUSARI KABUPATEN JEMBER Analysis of Potential Lead Pollution on Soil , Leachate and Ground Water ( MonitoringWells ) in Pakusari Landfill Jember. Artikel Ilmiah Hasil Penelitian Mahasiswa 2013. hal.1-8.

Witoelar R. 2005. Prosiding Pengujian Kualitas Bahan Bakar di 10 Kota Besar di Indonesia Proceeding of Fuel Quality Monitoring in 10 Big Cities in Indonesia Pendahuluan Prosiding Pengujian Kualitas Bahan Bakar di 10 Kota Besar di Indonesia Proceeding of Fuel Quality Monito. Prosiding Pengujian Kualitas Bahan Bakar di 10 Kota Besar di Indonesia. hal.1-60. 